\title{
Evaluating the Labour Market Integration of New Immigrants in the UK
}

\section{Tommaso Frattini}

University of Milan, LdA, CReAM and IZA

E-mail: tommaso.frattini@unimi.it

This article analyses the labour market integration of newly arrived immigrants in the UK labour market, based on data from the UK Labour Force Survey. We focus on immigrants who arrived in the United Kingdom since 2000 and distinguish different cohorts based on the year of their arrival in the country. We examine the extent to which these new arrivals were able to enter work and move up into skilled jobs, and analyse the sectors of the economy that have proved most amenable to this progression. The analysis indicates that these new arrivals fared relatively well in the workforce. In part as a result of their relative youth and high education levels, many new arrivals (especially those from the European Union and in particular the EU10 countries) moved straight into work.

Keywords: Immigration, integration, labour market, recent immigrants.

\section{Introduction}

The United Kingdom has long received immigrants from across the globe, but its immigrant population has experienced fast growth in recent years: according to the UK Labour Force Survey, between 2002 and 2015, the foreign-born population increased by over 75 per cent, from about 4.9 million to 8.6 million in 2015, or from 8.3 per cent to 13.4 per cent of the total population. Although the share of foreign-born amongst the overall population is smaller in the UK than in many other European countries, and the inflow of immigrants into the UK over the past one and a half decades has been more modest than that experienced by some other European countries (Alfano et al., 2016), the UK is one of the European countries where public opinion is relatively more concerned about immigration. Immigration has also dominated the debate that has led to the so-called Brexit referendum held on 23 June 2016, where concerns about migrants' alleged overreliance on welfare state provisions and little integration into the labour market were often voiced. Yet, as is often the case when immigration is publicly discussed, the debate was not always based on careful factual analysis, but on firmly held convictions informed by anecdotal evidence.

This article provides an overview of the labour market integration of the cohort of immigrants that entered the UK between 2000 and 2012. It assesses the extent to which these new arrivals were able to enter work and move up into skilled jobs, and surveys the sectors of the economy that have proven most amenable to this progression. In particular, we will study their integration relative to UK born natives in terms of employment probability, occupational distribution and employment sectors.

The analysis is based on the UK Labour Force Survey (LFS), a quarterly survey of about 60,000 households conducted by the Office for National Statistics. The LFS is the largest 
and longest-standing nationally representative continuous survey available in the UK. However, the LFS was not especially designed for the study of immigration. Therefore, the number of sampled immigrants is relatively small, as it reflects the proportion of immigrants in the total population. The limited sample size prevents too fine a breakdown of the sample across industry, occupation and country of origin lines.

In this article, we use the LFS for the years 2000-12, pooling together all quarters within each year (i.e. using all available quarters, rather than focusing on one only quarter per year) to increase the sample size. Throughout the text, 'immigrants' are defined as 'foreign-born', and 'recent' immigrants are those who arrived in the United Kingdom since 2000. The EU10 refers to the Central and Eastern European countries that joined the European Union in 2004, the so-called 'A8 countries', namely Czech Republic, Estonia, Hungary, Latvia, Lithuania, Poland, Slovakia, and Slovenia, or in 2007, namely Bulgaria and Romania, the A2 countries. We will always compare three groups, based on individuals' country of birth: natives, European Economic Area (EEA) immigrants (including from Switzerland) and non-EEA immigrants. ${ }^{1}$ We restrict our sample to the working age (eighteen to sixty-four) population only, and focus in particular on immigrants who arrived in the UK since 2000. Additionally, the study assesses outcomes for five cohorts arriving between 2000 and 2009, separated according to their years of arrival in the United Kingdom. The first cohort are those who arrived between 2000 and 2001; the second cohort between 2002 and 2003; and so on. We classify occupations based on the Standard Occupational Classification 2000 (SOC 2000), and sectors of activity based on the Standard Industrial Classification $1992(\mathrm{SIC})^{2}$

\section{Immigration in the UK}

Immigration to the UK has increased considerably over the last decade or so: the working age (eighteen to sixty-four) foreign-born population grew by over 70 per cent between 2000 and 2012, from about 3.5 to 6 million, or from 9.7 per cent to 15.6 per cent of the total working age population (see Figure 1).

While the UK has historically been the destination of immigrants from all origins, one of the key defining moments of recent British migration history has been the EU eastern enlargement of 2004. The UK, like Ireland and Sweden but unlike the other EU member countries, imposed virtually no restrictions to the access of citizens of the new member states (which came to be collectively called A8 countries) to its labour market. The years following the EU enlargement saw therefore a rise in immigration from A8 countries: as Figure 1 shows, between 2006 and 2007 alone the stock of immigrants from EEA countries increased by about 1 per cent of the size of the working age population. ${ }^{3}$ Some studies have focused on the consequences of such immigration inflows for UK natives, and found no sign of any adverse effects on public finances (see Dustmann et al., 2010; Dustmann and Frattini, 2014) and on natives' labour market prospects (see Lemos and Portes, 2008; Alfano et al., 2016 provide a concise review). In this article, we focus instead on the immigrants' experience, and provide an overview of the integration of the recent cohorts of immigrants into the UK labour market.

Table 1 reports some summary characteristics of recent immigrants to the UK, and compares them to natives. Recent immigrants are substantially younger than natives: EEA and particular EU10 workers are especially likely to be young (with an average age of thirty-one and thirty respectively), while immigrants from outside the European Union are 
Table 1 Characteristics of recent UK immigrants and natives, 2000-12

\begin{tabular}{|c|c|c|c|c|c|c|}
\hline & $\begin{array}{l}\text { (1) } \\
\text { Average } \\
\text { age }\end{array}$ & $\begin{array}{l}(2) \\
\text { Share } \\
\text { women }\end{array}$ & $\begin{array}{l}\text { (3) } \\
\text { Share } \\
\text { high } \\
\text { education }\end{array}$ & $\begin{array}{l}\text { (4) } \\
\text { Share } \\
\text { low } \\
\text { education }\end{array}$ & $\begin{array}{l}\text { (5) } \\
\text { Share high } \\
\text { education } \\
(25-35)\end{array}$ & $\begin{array}{l}\text { (6) } \\
\text { Share low } \\
\text { education } \\
(25-35)\end{array}$ \\
\hline $\begin{array}{l}\text { Natives } \\
\text { Recent immigrants }\end{array}$ & 40.8 & 0.50 & 0.16 & 0.52 & 0.26 & 0.43 \\
\hline EEA & 30.6 & 0.50 & 0.41 & 0.09 & 0.51 & 0.07 \\
\hline EU10 & 30.4 & 0.50 & 0.37 & 0.09 & 0.47 & 0.07 \\
\hline Other EEA & 31.0 & 0.51 & 0.49 & 0.11 & 0.61 & 0.08 \\
\hline $\begin{array}{l}\text { Non-EEA } \\
\text { Arrival cohorts }\end{array}$ & 32.2 & 0.50 & 0.42 & 0.14 & 0.51 & 0.12 \\
\hline 2000-01 & 33.1 & 0.50 & 0.40 & 0.16 & 0.46 & 0.15 \\
\hline 2002-03 & 32.3 & 0.50 & 0.41 & 0.14 & 0.49 & 0.12 \\
\hline 2004-05 & 31.7 & 0.49 & 0.42 & 0.11 & 0.51 & 0.08 \\
\hline 2006-07 & 30.8 & 0.50 & 0.43 & 0.10 & 0.55 & 0.08 \\
\hline 2008-09 & 29.5 & 0.49 & 0.41 & 0.10 & 0.55 & 0.08 \\
\hline
\end{tabular}

Source: Author's analysis based on UK Labour Force Survey (LFS).

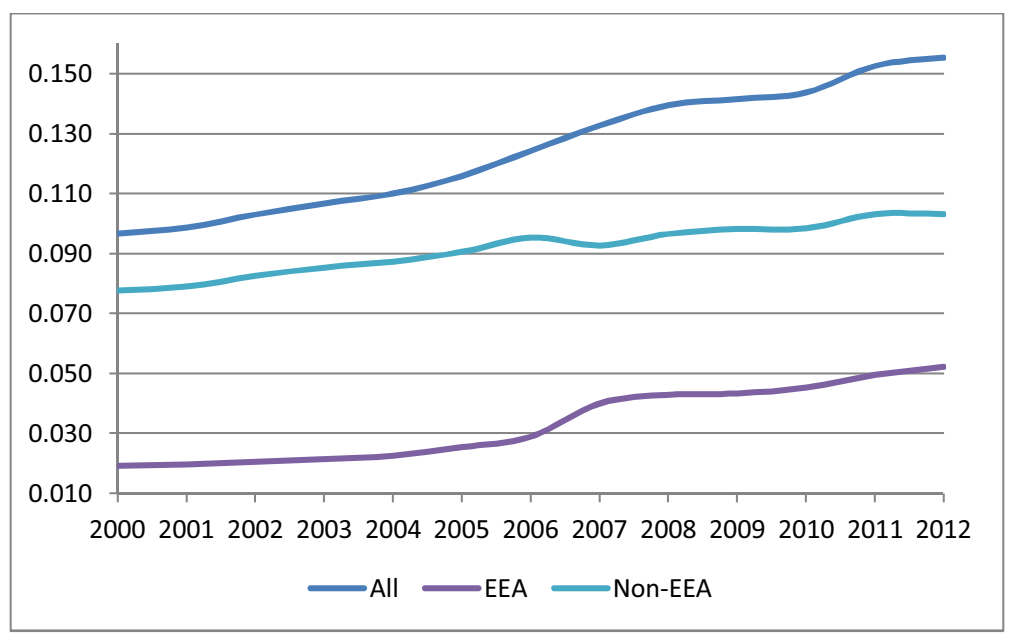

Figure 1. (Colour online) Working age immigrants as a share of total UK population, 2000-12 Source: Author's analysis based on UK Labour Force Survey (LFS).

slightly older (thirty-two) compared to an average age of forty-one for natives. As expected, the gender composition of working age natives is balanced, with a 50 per cent share of women. Perhaps less obviously, the same gender balance also applies to the recent cohorts of immigrants, irrespective of their origin. Columns 2 and 3 of Table 1 report the share of immigrants and natives with 'High' or 'Low' levels of education (we exclude individuals who are still in full-time education). We define as 'highly educated' individuals who left full-time education at age twenty-one or later, and as 'low educated' individuals who left full-time education before seventeen. Although these are admittedly imperfect measures 
of education - which, for instance, do not allow for country differences in school starting age or in the number of years of high school - they are the best available measure of immigrants' education in the UK LFS for most of the period covered in the analysis. Until the end of 2010, in fact, the UK LFS was recording all foreign educational qualifications as 'other qualifications', which makes it problematic to compare immigrants' and natives' educational levels for the period prior to the end of $2010 .^{4}$ The educational level of recent immigrants is significantly higher than that of natives. The share of highly educated individuals is higher than 40 per cent for both EEA and non-EEA immigrants, but it stands at 16 per cent for UK natives. Further, the share of individuals with 'low' education is 52 per cent among natives, but just 9 per cent and 14 per cent among recent EEA and non-EEA immigrants, respectively. Note that the educational advantage of immigrants is not only due to the different age composition of the native and immigrant populations: even within the age bracket twenty-five and thirty-five, the share of highly educated is 26 per cent among natives but 51 per cent for recent EEA and non-EEA immigrants, and the share of low educated individuals is 43 per cent among natives but 7 per cent and 12 per cent for recent EEAs and non-EEAs.

\section{Employment}

In 2012, the employment rate (ratio of the number of employed to the working age population) of immigrants was 68 per cent, while the employment rate of natives was higher at 73 per cent. However, stark differences exist in the immigrant population: EEA immigrants' employment rate is higher than natives' at 76 per cent, while the employment rate of non-EEA is less than 64 per cent. Immigrants are also characterised by a higher inactivity rate (ratio of the number of people out of the labour market to working age population) than natives: 25 per cent vs. 21 per cent, respectively. EEA immigrants display a higher labour market integration than natives, with a inactivity rate of 18 per cent, while non-EEA immigrants have a higher rate of inactivity at 29 per cent.

How do recently arrived immigrants fare relative to natives and to the whole immigrant population? Figure 2 reports the evolution over time of the employment rate of natives and immigrants since 2000.

The employment rate of natives is relatively stable at about 75 per cent, although it drops to around 73 per cent after 2008 as a consequence of the economic crisis. The employment rate of recent immigrants on the contrary increases substantially over time. Non-EEA immigrants, in particular, start off with a substantially lower employment rate than natives, but then both immigrant groups experience a similar growth in employment probability, which peaks in 2006-08 and then slightly decreases when the economic crisis starts.

In Figure 3, we display separately the evolution over time of the employment rate of immigrants who arrived in 2000-01, 2002-03, 2004-05, 2006-07 and 2008-09. The graph clearly shows that successive immigrant cohorts perform increasingly better - in terms of their employment probability - in the UK labour market upon arrival, but this regularity breaks down with the 2006-07 cohort, which has a very similar performance to the previous cohort, and with the 2008-09 cohort, which performs consistently worse. After one year in the UK, the employment rate of immigrants who arrived in 2000-01 was 59 per cent, while it was 63 per cent for those who arrived in 2002-03 and 70 per cent for those who arrived in 2004-05 and in 2006-07; conversely the employment rate after 


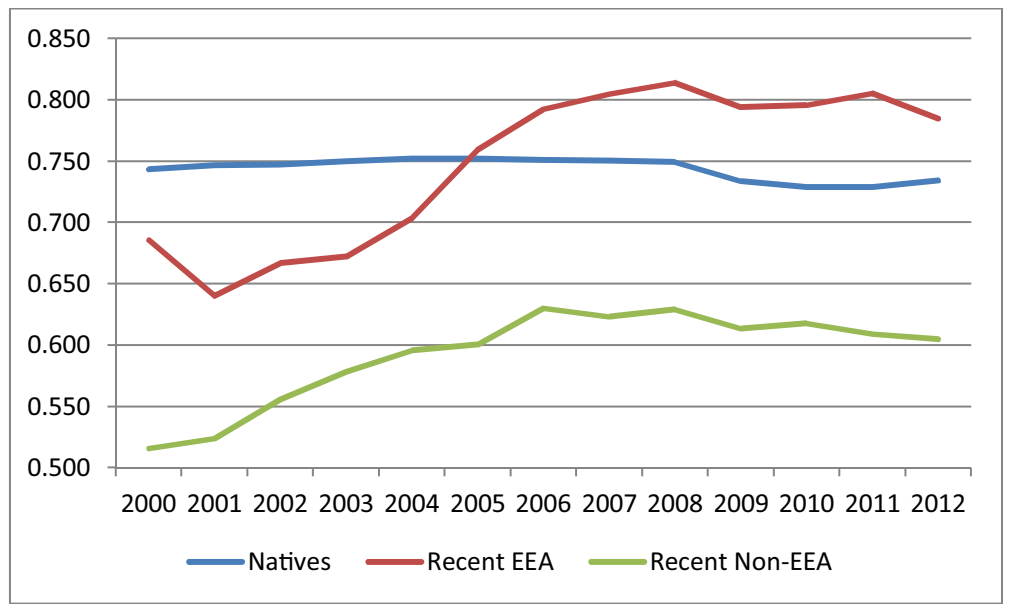

Figure 2. (Colour online) Employment rate

Source: Author's analysis based on UK Labour Force Survey (LFS).

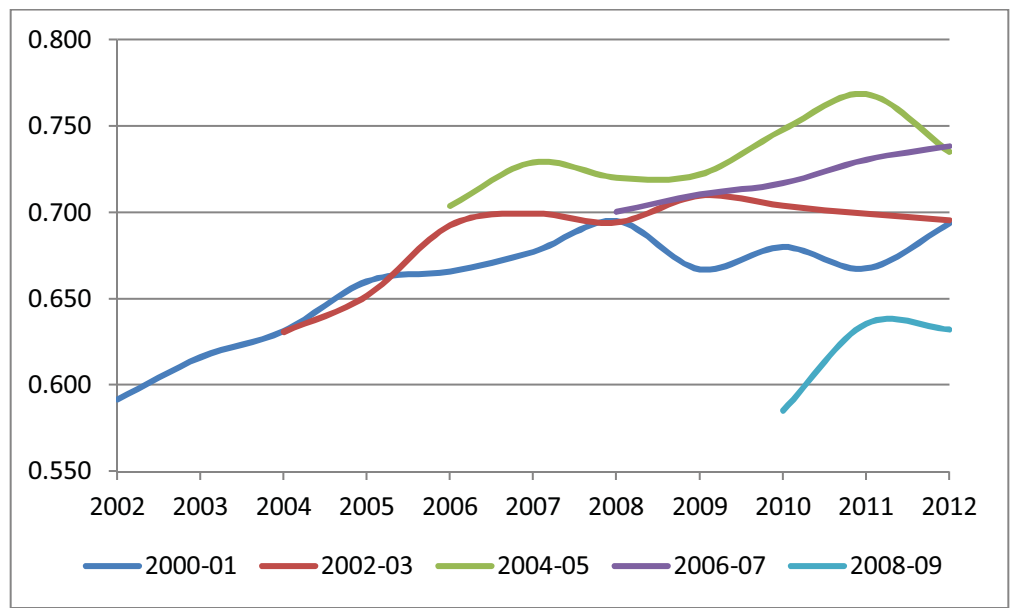

Figure 3. (Colour online) Employment rate by entry cohort

Source: Author's analysis based on UK Labour Force Survey (LFS).

one year in the UK of immigrants who arrived in 2008-09, i.e. when the crisis started, was only 58.5 per cent. Further, all cohorts display an increase in their employment probability with time spent in the UK, and the pace of such an increase (i.e. the slope of the lines in Figure 3) is very similar across cohorts, with the partial exception of the most recent arrivals. We should also note that in the absence of a longitudinal sample we are not able to disentangle the fraction of increase in employment that is due to labour market assimilation from the fraction due to negatively selected return migration. ${ }^{5}$

What would be the difference between the employment rate of recent cohorts of immigrants and natives if they were similar in terms of gender composition, age structure 
Table 2 Differences in employment probability between natives and "similar" immigrants

\begin{tabular}{ccccc}
\hline \hline & \multicolumn{4}{c}{ Immigrants and natives made similar in terms of: } \\
\cline { 2 - 5 } & $\begin{array}{c}\text { A } \\
\text { Observation year }\end{array}$ & $\begin{array}{c}\text { B } \\
\text { A + gender }\end{array}$ & $\begin{array}{c}\text { C } \\
\text { B + age }\end{array}$ & $\begin{array}{c}\text { D } \\
\text { C education }\end{array}$ \\
\hline Panel I: by origin & & & & \\
EEA & 0.047 & 0.048 & 0.009 & -0.017 \\
Non-EEA & -0.130 & -0.129 & -0.176 & -0.184 \\
\hline Panel II: by arrival cohorts & -0.095 & -0.145 & -0.163 \\
2000-01 & -0.097 & -0.067 & -0.115 & -0.128 \\
2002-03 & -0.068 & -0.023 & -0.068 & -0.084 \\
2004-05 & -0.023 & -0.038 & -0.077 & -0.093 \\
2006-07 & -0.039 & -0.146 & -0.178 & -0.166 \\
2008-09 & -0.147 & & & \\
\hline \hline
\end{tabular}

Source: Author's analysis based on UK Labour Force Survey (LFS).

and education? We address this question through the use of regression analysis, which allows us to compare immigrants and natives with the same characteristics. ${ }^{6}$

Table 2 reports differences in employment probability between recent immigrants and natives for the years 2000-12, where immigrants and natives are seen to be increasingly similar as we move across columns from A to D. In column A, we compare immigrants and natives within the same observation year: this allows us to make sure that differences in business cycle over the thirteen years considered do not drive the results. EEA immigrants are on average 5 percentage points more likely than natives to be employed, while the employment probability of non-EEAs is 13 percentage points lower. In column B, we compare natives and immigrants with the same gender: the results are almost identical to those of column A. This is not surprising as Table 1 shows that the gender composition of recent immigrants and natives is very similar. However, Table 1 also shows that recent immigrants are younger and better educated than natives. What happens if we make EEAs and non-EEAs identical to natives with respect to age, in addition to gender? Column C shows that this worsens the employment outcomes of both immigrant groups relative to natives: recent EEA immigrants with the same gender-age profile as natives are in every given year less than 1 percentage point more likely than their native counterparts of having a job, while for non-EEA immigrants the employment gap increases to 18 percentage points. Finally, in column D we compare natives to recent immigrants with the same gender-age-education profile: the outcome is strikingly different from the unconditional comparison. A recent EEA immigrant is almost 2 percentage points less likely to have a job than a comparable native, while the gap in employment probability for non-EEA recent immigrants increases to 18 percentage points.

Overall, panel I of Table 2 indicates therefore that the employment probability advantage of EEA immigrants relative to natives is entirely due to their younger age and higher education, while the employment gap of non-EEA immigrants would be even larger were it not for their favourable education-age profiles. This finding of a persistent gap for non-European immigrants can be traced down to the lower portability of their human capital (Friedberg, 2000): existing levels of education, experience and training can 
be less valued in the UK labour market for non-European than for European immigrants. However, since many of the non-EEA immigrants have a different ethnic origin from UK natives, we cannot rule out that ethnic discrimination (Becker, 1971; Cain, 1986) may also play a role. Indeed, there is evidence for the UK labour market that non-white immigrants have important labour market penalties in terms of both lower wages and lower employment rates, even after accounting for a standard range of personal and work-related characteristics (Wheatley Price, 2001; Blackaby et al., 2002; Clark and Lindley, 2009).

In panel II of Table 2, we report a similar analysis for the five cohorts of immigrants who arrived between 2000 and 2009, which have been previously studied. As expected, the gap in employment probability between immigrants in each cohort and natives increases as immigrants are made 'more similar' to natives. Interestingly, however, the status of each cohort relative to the others is not affected by the age-distribution profiles of its members, with the 2004-05 cohort having the lowest employment probability gap for every year, and the 2008-09 cohort having the highest. The differences in gaps between cohorts are however lower when differences in the gender-age-education profiles are taken into account.

\section{Occupational distribution}

Employment is only one dimension of labour market integration. Another important dimension in evaluating the role of immigrants in the UK labour market is to analyse their occupational distribution compared to that of natives. Table 3 reports the occupational distribution of immigrants and natives in 2012, where occupations are grouped into the nine SOC major groups. Occupation grouping is designed to reflect the general level of qualifications, training, skills and experience commonly associated with the competent performance of work tasks for each group. Occupations are ranked by decreasing level of skills required for each occupation. The last column reports the median hourly pay for each occupation over the period 2000-12, expressed in 2005£UK. Immigrants are 66 per cent more likely than natives to be employed in elementary occupations, the least-skilled and least-paid occupational category. On the other hand, the proportion of immigrants in the highest-paid occupational category, professional occupations, is higher (16.5 per cent) than that of natives (13 per cent). Immigrants' occupational distribution tends therefore to be U-shaped, with a higher concentration at the top and at the bottom of the occupational scale. Non-EEA immigrants tend to have better occupational outcomes than EEAs, as they are less likely to be employed in elementary occupations (13 per cent vs. 23 per cent) and are more likely to be employed in high-skill and high-pay occupations. The occupational distribution of recent immigrants is similar to that of the overall immigrant population, although they are more concentrated in low-skilled occupations and slightly less concentrated in the higher skilled occupational categories. In order to understand whether their lower occupational performance is due to some unfavourable characteristics of recent immigrant cohorts or simply due to a shorter residence in the UK, in Figure 4 we look at the evolution of the share of immigrants in unskilled occupations for recent immigrant cohorts over time. ${ }^{7}$

The proportion of individuals in elementary occupations upon arrival in the UK is lowest for immigrants who arrived in 2000-01 (20 per cent), but it increases steadily over successive cohorts up to 33 per cent for the 2008-09 arrival cohort. Moreover, for 
Table 3 Occupational distribution of immigrants and natives, 2012

\begin{tabular}{|c|c|c|c|c|c|c|c|}
\hline & \multirow[b]{2}{*}{ Natives } & \multicolumn{3}{|c|}{ Immigrants } & \multicolumn{2}{|c|}{$\begin{array}{l}\text { Recent } \\
\text { immigrants }\end{array}$} & \multirow[b]{2}{*}{$\begin{array}{l}\text { Median hourly } \\
\text { pay }\end{array}$} \\
\hline & & All & $E E A$ & $\begin{array}{l}\text { Non- } \\
E E A\end{array}$ & $E E A$ & $\begin{array}{l}\text { Non- } \\
E E A\end{array}$ & \\
\hline $\begin{array}{l}\text { Managers and senior } \\
\text { officials }\end{array}$ & 0.158 & 0.135 & 0.122 & 0.142 & 0.076 & 0.124 & 14.1 \\
\hline $\begin{array}{l}\text { Professional } \\
\text { occupations }\end{array}$ & 0.131 & 0.165 & 0.132 & 0.185 & 0.100 & 0.183 & 15.0 \\
\hline $\begin{array}{l}\text { Associate professional } \\
\text { and technical }\end{array}$ & 0.162 & 0.148 & 0.127 & 0.162 & 0.107 & 0.160 & 11.3 \\
\hline $\begin{array}{l}\text { Administrative and } \\
\text { secretarial }\end{array}$ & 0.116 & 0.073 & 0.065 & 0.079 & 0.054 & 0.062 & 7.8 \\
\hline $\begin{array}{l}\text { Skilled trades } \\
\text { occupations }\end{array}$ & 0.107 & 0.085 & 0.111 & 0.070 & 0.126 & 0.065 & 8.3 \\
\hline $\begin{array}{l}\text { Personal service } \\
\text { occupations }\end{array}$ & 0.089 & 0.083 & 0.066 & 0.093 & 0.057 & 0.111 & 6.4 \\
\hline $\begin{array}{l}\text { Sales and customer } \\
\text { service occupations }\end{array}$ & 0.076 & 0.062 & 0.047 & 0.072 & 0.052 & 0.080 & 5.7 \\
\hline $\begin{array}{l}\text { Process, plant and } \\
\text { machine operatives }\end{array}$ & 0.062 & 0.082 & 0.104 & 0.069 & 0.135 & 0.057 & 7.3 \\
\hline $\begin{array}{l}\text { Elementary } \\
\text { occupations }\end{array}$ & 0.099 & 0.166 & 0.227 & 0.129 & 0.293 & 0.158 & 5.7 \\
\hline
\end{tabular}

Source: Author's analysis based on UK Labour Force Survey (LFS).

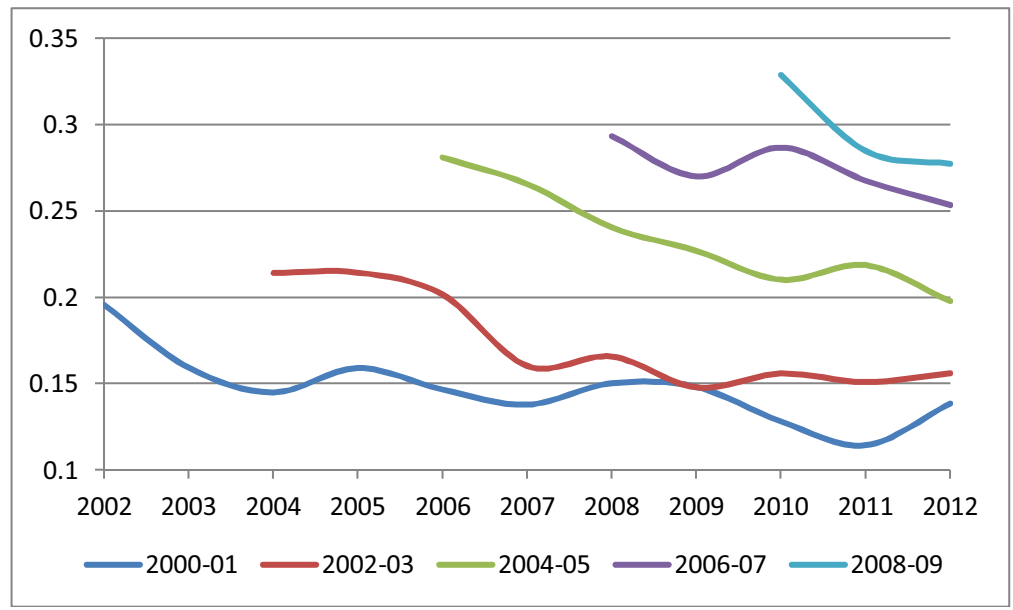

Figure 4. (Colour online) Elementary occupations by entry cohort Source: Author's analysis based on UK Labour Force Survey (LFS).

all cohorts the proportion of employed individuals in elementary occupations decreases over time.

It is worth noting that Figure 4 looks very similar to the mirror image of Figure 3, which suggests that the occupational distribution may have to do with selective labour 
Table 4 Differences in probability of being in elementary occupations

\begin{tabular}{llccc}
\hline \hline & \multicolumn{4}{c}{ Immigrants and natives made similar in terms of: } \\
\cline { 2 - 5 } & $\begin{array}{c}\text { A } \\
\text { Observation year }\end{array}$ & $\begin{array}{c}\text { B } \\
\text { A + gender }\end{array}$ & $\begin{array}{c}\text { C } \\
\text { B + age }\end{array}$ & $\begin{array}{c}\text { D } \\
\text { C + education }\end{array}$ \\
\hline Panel I: by origin & & & \\
EEA & 0.193 & 0.192 & 0.185 & 0.228 \\
Non-EEA & 0.067 & 0.067 & 0.068 & 0.107 \\
Panel II: by arrival cohorts & & & \\
2000-01 & 0.043 & 0.043 & 0.046 & 0.089 \\
2002-03 & 0.073 & 0.073 & 0.073 & 0.113 \\
2004-05 & 0.137 & 0.137 & 0.134 & 0.177 \\
2006-07 & 0.180 & 0.180 & 0.173 & 0.216 \\
2008-09 & 0.194 & 0.194 & 0.184 & 0.220 \\
\hline
\end{tabular}

Source: Author's analysis based on UK Labour Force Survey (LFS).

market participation: earlier cohorts have lower employment rates, but better occupational outcomes than more recent cohorts.

It has been recorded (e.g. Dustmann et al., 2013) that recent cohorts of immigrants in the UK suffer an 'occupational downgrading', i.e. they tend to be employed in occupations for which they are over-qualified (see also the related literature on the ethnic penalty, e.g. Heath and McMahon, 1997; Berthoud, 2000; Heath and Cheung, 2006; Simpson et al., 2006). The analysis of Table 4, which is similar to Table 2 on employment probability, allows us to address this issue. ${ }^{8}$

Column A of Table 4 shows that in every year recent EEA immigrants are 19 percentage points more likely than natives to be employed in elementary occupations, while the probability gap is 7 percentage points for recent non-EEA immigrants. As expected, column B shows that this difference does not arise because of dissimilarities in gender composition between immigrants and natives. Rather, part of the higher probability of falling in the lowest skilled occupational category can be explained, for recent EEA immigrants, by their younger age: when we compare similarly aged natives and recent immigrants, the likelihood of being employed in elementary occupations decreases to 18.5 percentage points for EEAs, while it is essentially unaffected for non-EEAs. When we compare recent immigrants and natives that are similar also in terms of education, however, the gap increases for all immigrant groups: a recent EEA (non-EEA) immigrant is 23 (11) percentage points more likely to be employed in an elementary occupation than a native with the same gender-age-education profile. The table confirms therefore the existence of a substantial occupational downgrading of recent immigrants in the UK labour market.

Panel II of Table 4 indicates that all recent cohorts of immigrants suffer some occupational downgrading - for all cohorts the difference in probability of being employed in an elementary occupation with respect to a native is higher when their education is taken into account. The downgrading is higher for more recent arrival cohorts, which are more likely than earlier cohorts to work in unskilled occupations despite their higher level of education (see Table 1). 
Table 5 Sector distribution of immigrants and natives, 2012

\begin{tabular}{|c|c|c|c|c|c|c|c|c|}
\hline & \multirow[b]{2}{*}{ Natives } & \multicolumn{3}{|c|}{ Immigrants } & \multicolumn{2}{|c|}{$\begin{array}{l}\text { Recent } \\
\text { immigrants }\end{array}$} & \multicolumn{2}{|c|}{$\begin{array}{l}\text { Proportion of } \\
\text { jobs that are }\end{array}$} \\
\hline & & All & EEA & $\begin{array}{l}\text { Non- } \\
\text { EEA }\end{array}$ & EEA & $\begin{array}{l}\text { Non- } \\
\text { EEA }\end{array}$ & $\begin{array}{l}\text { High } \\
\text { skilled }\end{array}$ & $\begin{array}{l}\text { Low } \\
\text { skilled }\end{array}$ \\
\hline $\begin{array}{l}\text { Agriculture and } \\
\text { fishing }\end{array}$ & 0.016 & 0.008 & 0.017 & 0.002 & 0.021 & 0.002 & 0.126 & 0.238 \\
\hline Energy and water & 0.014 & 0.007 & 0.007 & 0.007 & 0.006 & 0.008 & 0.432 & 0.245 \\
\hline Manufacturing & 0.110 & 0.101 & 0.148 & 0.072 & 0.179 & 0.073 & 0.334 & 0.291 \\
\hline Construction & 0.075 & 0.054 & 0.083 & 0.036 & 0.093 & 0.038 & 0.213 & 0.161 \\
\hline $\begin{array}{l}\text { Distribution, hotels } \\
\text { and restaurants }\end{array}$ & 0.181 & 0.220 & 0.215 & 0.224 & 0.245 & 0.229 & 0.256 & 0.481 \\
\hline $\begin{array}{l}\text { Transport and } \\
\text { communication }\end{array}$ & 0.058 & 0.078 & 0.070 & 0.082 & 0.080 & 0.065 & 0.235 & 0.478 \\
\hline $\begin{array}{l}\text { Banking, finance and } \\
\text { insurance }\end{array}$ & 0.174 & 0.213 & 0.205 & 0.218 & 0.192 & 0.242 & 0.553 & 0.139 \\
\hline $\begin{array}{l}\text { Public administration, } \\
\text { education and } \\
\text { health }\end{array}$ & 0.308 & 0.267 & 0.197 & 0.310 & 0.135 & 0.294 & 0.494 & 0.075 \\
\hline Other services & 0.064 & 0.053 & 0.057 & 0.050 & 0.049 & 0.049 & 0.390 & 0.175 \\
\hline
\end{tabular}

Source: Author's analysis based on UK Labour Force Survey (LFS).

\section{Sectoral distribution}

Finally, we analyse the distribution of employed immigrants and natives across SIC sectors. There are no major differences in the sector of activity of natives and of immigrants in general, although immigrants tend to be more concentrated than natives in the sectors of distribution, hotels and restaurants, in transport and communications and in banking, as we show in Table 5.

Some differences are evident instead between the sectors of employment of EEA and non-EEA immigrants: EEAs are twice as likely as non-EEAs to be employed in manufacturing (15 per cent vs. 7 per cent) and construction (8 per cent vs. 4 per cent), while non-EEAs have a substantially higher concentration than EEAs in public administration, education and health (31 per cent vs. 20 per cent).

When we restrict attention to immigrants who arrived since 2000, some more differences emerge between immigrants and natives, and between natives of different origins. Recent EEA immigrants are ten times more likely than non-EEAs to work in agriculture (2 per cent vs. 0.2 per cent), and they are more concentrated in manufacturing (18 per cent) and in hotels and restaurants (24.5 per cent) than earlier immigrants. Recent immigrants from all origins are less likely to work in banking and finance and in public administration, education and health - the sectors with the highest concentration of high skilled jobs, ${ }^{9}$ as indicated in the last two columns of the table - than earlier immigrants.

In Figure 5, we focus on the cohort of immigrants who arrived in the UK between 2000 and 2001, and show how their concentration in some of the most immigrantintensive sectors evolved with time spent in the UK. The figure shows that the proportion of immigrants employed in distribution, hotels and restaurants fluctuated over time but 


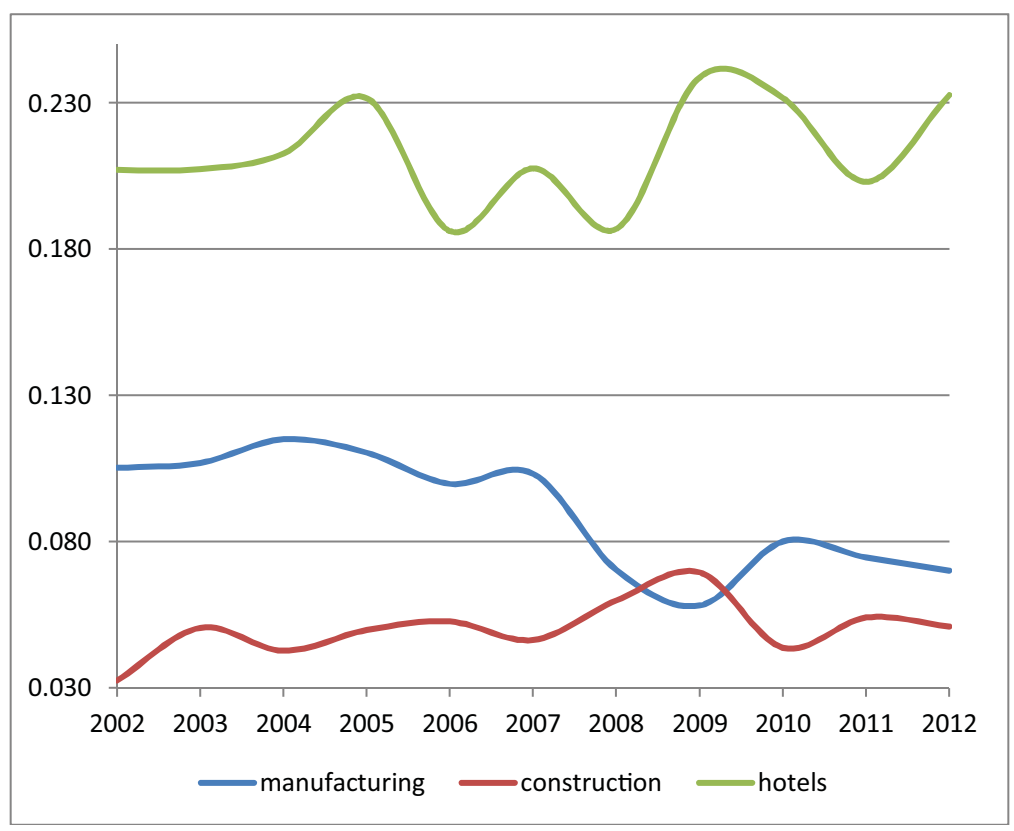

Figure 5. (Colour online) Sectorial concentration over time, 2000-01 entry cohort

remained relatively constant at just above 20 per cent. Conversely, the proportion of immigrant workers in manufacturing exhibits a clear downward trend, decreasing from 10.5 per cent in 2002 to 7 per cent in 2012, while the share of workers in construction increased slightly over time, from 3 per cent to 5 per cent.

\section{Concluding remarks}

The United Kingdom has experienced sizeable growth in its foreign-born population since 2000. Newcomers are younger and better-educated than UK natives, but they are characterised by a lower probability of employment and a higher concentration in unskilled occupations, especially in the first years after arrival, though there is a strong variation across sub-groups. This indicates that the labour market integration of recent arrivals tends to improve with time spent in the United Kingdom, a pattern that is common to all recent entry cohorts in terms of both employment probability and occupational upgrading. ${ }^{10}$ EEA workers have better labour market outcomes than those from non-EEA countries, and they also have a higher employment probability than natives, after some time spent in the UK.

Some commentators have voiced criticism about the British decision in 2004 to refrain from imposing restrictions on workers from Eastern Europe, resulting in a significant influx of new workers. Some communities which received large numbers of EU10 workers, particularly in some northern and/or rural areas, were unaccustomed to immigration and unprepared for it, resulting in some pressure on public services - and, in some cases, negative public attitudes, especially when change was rapid. The sources of public anxiety 
are many, ranging from fear about competition for jobs, to a sense of unfairness about these workers' eligibility for social benefits, to concern on their behalf about working conditions and exploitation. Public concerns about the scale of immigration from the countries which joined the EU in 2004 led the UK government to impose restrictions on immigration of citizens from Bulgaria and Romania. These restrictions were eventually lifted only in January 2014, amidst fears of a rapid rise in immigration from these countries.

Despite these worries, the employment rates of EU10 workers are the highest of newcomers of all backgrounds. The findings of this article suggest that these outcomes are largely the result of this population's favourable age and education profile, which indicates that the UK, in contrast to other European countries, is able to attract a favourably selfselected immigrant population, even from EU countries, from which immigration cannot be selected.

These workers are also overrepresented in unskilled jobs. However, as new immigrants spend time in the country, and learn relevant country-specific skills, most notably the language, they tend to move up the occupational ladder. The policy challenge in this case is to avoid a situation where a long stay in unskilled occupations may lead to a depreciation of immigrants' human capital, thus wasting a precious and freely available resource.

\section{Acknowledgements}

I wish to thank Meghan Benton for her insightful comments and suggestion on earlier drafts of this article. This article is based on the report 'Moving Up the Ladder? Labor Market Outcomes in the United Kingdom amid Rising Immigration' prepared for the Migration Policy Institute, which I gratefully acknowledge for funding this research. Material from the Quarterly Labour Force Survey is Crown Copyright and has been made available by the Office for National Statistics (ONS) through the UK Data Service.

\section{Notes}

1 EEA countries are: Austria, Belgium, Bulgaria, Cyprus, Czech Republic, Denmark, Estonia, Finland, France, Germany, Greece, Hungary, Republic of Ireland, Italy, Latvia, Liechtenstein, Lithuania, Luxembourg, Malta, The Netherlands, Norway, Poland, Portugal, Romania, Slovakia, Slovenia, Spain, Sweden. In the analysis, we include Switzerland in this group because, although not being formally part of the EEA, it is linked to the EU by a series of bilateral agreements.

2 Note that the classifications of both occupations and sectors adopted in the UK LFS have changed over time. In particular, occupations were coded according to SOC90 until year 2000, according to SOC2000 between years 2001 and 2010, and according to SOC2010 since 2011. We use the double coding of occupations in both SOC2000 and SOC2010 available in the LFS quarters 1-3 for year 2010 to map all 4-digits SOC2010 categories in years 2011 and 2012 into SOC2000. We instead exclude from the occupational analysis year 2000.

Industrial sectors were coded according to SIC92 until 2006. Since 2007, industrial sectors are coded according to SIC2007. However, the LFS also reports a conversion variable that allows mapping SIC2007 into SIC92 for all quarters.

3 The labour market integration of A8 immigrants has been studied by Drinkwater et al. (2009).

4 For a discussion of this issue, see the Appendix of Manacorda et al. (2012).

5 If the least successful migrants leave the UK earlier than those who have a better labour market performance, then the positive slope of the employment assimilation profile might not entirely be due to the fact that immigrants with a longer residence in the UK are more likely to find (and retain) a job, but 
also to the fact that immigrants who do not find a job leave the country and thus mechanically increase the fraction of employed individuals among the resident immigrant population.

6 Specifically, results in Table 2 are obtained from estimation of linear probability models where the dependent variable is a dummy for employment, and the regressors of interest are dummy variables for recent EEA and non-EEA immigrants (Panel I), or dummy variables for immigrants in successive immigrant cohorts (Panel II). In different specifications, we increasingly include as additional regressors: year dummies (column A), gender (column B), a quadratic form in age (column C) and dummies for three levels of education (column D). We estimate robust standard errors, and all displayed coefficients are statistically significant at 1 per cent.

7 It is also important to note the role that qualifications plays in the distribution of immigrants across occupations as many immigrants have found that qualifications obtained outside the UK are not initially, at least, recognised within the UK (see Rolfe's article in this issue).

8 Results in Table 4 are obtained from estimation of linear probability models similar to those in Table 2, but where the dependent variable is a dummy for being employed in an elementary occupation, and the sample consists of all individuals in employment. See footnote 6 for details.

9 We have grouped into 'high skill' occupations SOC major groups 1, 2 and 3 (Managers and Senior Officials; Professional occupations; Associate Professional and Technical), and into 'low skill' occupations SOC major groups 7, 8 and 9 (Sales and Customer Service Occupations; Process, Plant and Machine Operatives; Elementary Occupations).

10 We should, however interpret these findings with some caution because, in the absence of longitudinal data, we cannot disentangle the effect of labour market assimilation from selective return migration.

\section{References}

Alfano, M., Dustmann, C. and Frattini, T. (2016) 'Immigration and the UK: reflections after Brexit', in F. Fasani (ed.), Refugees and Economic Migrants: Facts, Policies and Challenges, CEPR Press, eBook. Becker, G. S. (1971) The Economics of Discrimination, 2nd edn, Chicago: University of Chicago Press.

Berthoud, R. (2000) 'Ethnic employment penalties in Britain', Journal of Ethnic and Migration Studies, 26, 3, 389-416.

Blackaby, D. H., Leslie, D. G., Murphy, P. D. and O'Leary, N. C. (2002) 'White/ethnic minority and employment differentials in Britain: evidence from the LFS', Oxford Economic Papers, 54, 270-97.

Cain, G. G. (1986) 'The economic analysis of labor market discrimination: a survey', Handbook of Labor Economics, 1, 693-785.

Clark, K. and Lindley, J. (2009) 'Immigrant assimilation pre and post labour market entry: evidence from the UK labour force survey', Journal of Population Economics, 22, 1, 175-98.

Drinkwater, S., Eade, J. and Garapich, M. (2009) 'Poles apart? EU enlargement and the labour market outcomes of immigrants in the UK', International Migration, 47, 1, 161-90.

Dustmann, C. and Frattini, T. (2014) 'The fiscal effects of immigration to the UK', Economic Journal, 124, 580, 593-643.

Dustmann, C., Frattini, T. and Halls, C. (2010) 'Assessing the fiscal costs and benefits of A8 migration to the UK', Fiscal Studies, 31, 1, 1-41.

Dustmann, C., Frattini, T. and Preston, T. (2013) 'The effect of immigration along the distribution of wages', Review of Economic Studies, 80, 1, 145-73.

Friedberg, R. M. (2000) 'You can't take it with you? Immigrant assimilation and the portability of human capital', Journal of Labor Economics, 18, 2, 221-51.

Heath, A. and Cheung, S. Y. (2006) 'Ethnic penalties in the labour market: employers and discrimination', Research Report No. 34, Department of Work and Pensions, London.

Heath, A. and McMahon, D. (1997) 'Education and occupational attainment: the impact of ethnic origins', in V. Karn (ed.), Education, Employment and Housing among Ethnic Minorities in Britain, London: HMSO, 91-113. 
Lemos, S. and Portes, J. (2008) 'New Labour? The impact of migration from central and eastern European countries on the UK labour market', IZA Discussion Papers 3756, Institute of Labor Economics, Bonn.

Manacorda, M., Manning, A. and Wadsworth, J. (2012) 'The impact of immigration on the structure of male wages: theory and evidence from Britain', Journal of the European Economic Association, 10, 1, 120-51.

Simpson, L., Purdam, K., Tajar, A., Fieldhouse, E., Gavalas, V., Tranmer, M. and Dorling, D. (2006) 'Ethnic minority populations and the labour market: an analysis of the 1991 and 2001 Census', Research Report 333, Department for Work and Pensions, London.

Wheatley Price, S. (2001) 'The employment adjustment of male immigrants in England', Journal of Population Economics, 14, 193-220. 